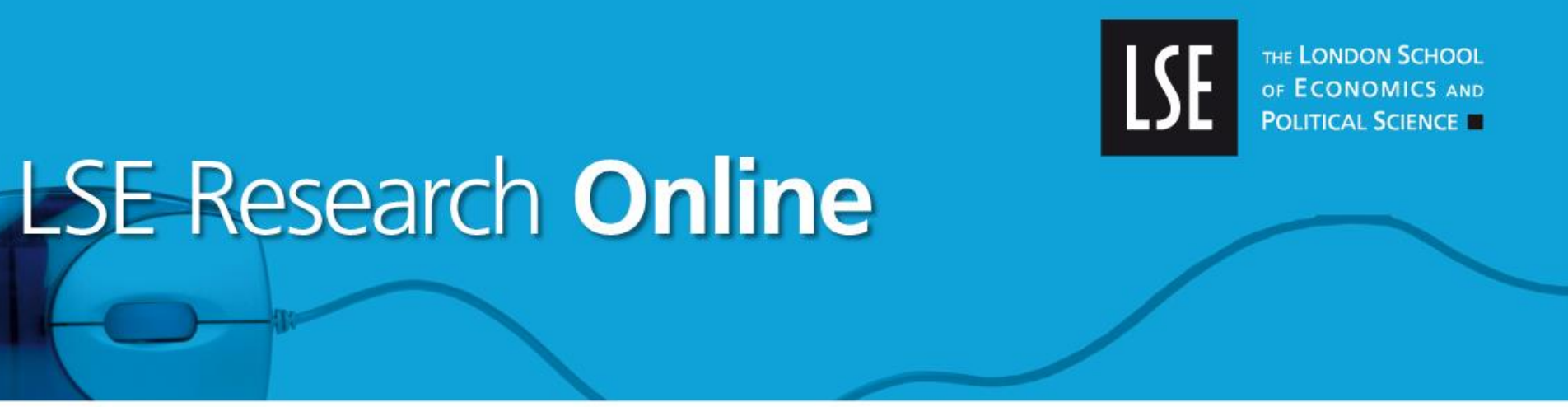

\title{
Monica Poletti
}

\section{The cognitive mobilization of organizational participation: missing evidence from Italy (1972-2006)}

\section{Article (Accepted version) (Refereed)}

Original citation: Poletti, Monica (2015) The cognitive mobilization of organizational participation: missing evidence from Italy (1972-2006). Electoral Studies, 40 . pp. 245-255. ISSN 0261-3794

DOI: $\underline{10.1016 / j . e l e c t s t u d .2015 .09 .003}$

Reuse of this item is permitted through licensing under the Creative Commons:

(C) 2015 The Author

CC-BY-NC-ND

This version available at: http://eprints.Ise.ac.uk/64335/

Available in LSE Research Online: November 2015

LSE has developed LSE Research Online so that users may access research output of the School. Copyright (C) and Moral Rights for the papers on this site are retained by the individual authors and/or other copyright owners. You may freely distribute the URL (http://eprints.Ise.ac.uk) of the LSE Research Online website. 
Paper published in Electoral Studies, Volume 40, December 2015, Pages 245-255

\title{
The Cognitive Mobilization of Organizational Participation: Missing Evidence from Italy (1972-2006)
}

MONICA POLETTI*

\begin{abstract}
The Cognitive Mobilization thesis (CM) claims that the increasing educational levels in postindustrial societies bring about changes in the relationship between people's education and their participatory behaviour compared to the past. Younger, well-educated and more politically interested citizens are less likely to participate in political parties than poorly educated citizens, but more likely to join unconventional types of activist organisations. Using Italy as a test case, this study looks at whether the $\mathrm{CM}$ mechanism ought to be considered as a key factor shaping organizational participatory trends over time. Contrary to the $\mathrm{CM}$ thesis, we find that the highly educated continue to participate the most in political parties and that the gap between well and poorly educated in terms of their participation in activist associations does not become larger compared to the past.
\end{abstract}

Keywords: cognitive mobilization, organizational participation, education effects, Italian politics

* Department of School and Political Sciences, University of Milan, via Conservatorio 7, 20122 Milan, Italy. European Institute, London School of Economics and Political Science, Houghton Street, WC2A 2AE, London, UK

Corresponding author contact details:

Monica Poletti, School of Politics and IR, Queen Mary University of London, Mile End Road, E1 4NS London, UK - m.poletti@qmul.ac.uk 


\section{Modernization and changing participatory behaviour}

Since the 1980s, in many Western democracies the relationship between political actors, political institutions and civil society has begun to come under pressure. Voters' turnout and membership levels in hierarchical political associations of advanced industrial democracies are now suffering a crisis (Dalton and Wattenberg, 2000, Franklin, 2004 and Van Biezen et al., 2012). This scenario, however, seems to be balanced by an expansion of new modalities of civil society participation. The most often used explanation in literature for these aggregate participatory trends is the theory of social modernization, and, in particular, the cognitive mobilization theory of citizens (hereafter CM) initially put forward by Inglehart, 1977 and Inglehart, 1990a. Although not by any means the only existing explanation, this theory has enjoyed a large degree of success within the academic community especially following its influential developement by Dalton, 1984 and Dalton, 2002 and other authors ( Fuchs and Klingemann, 1995, Pharr and Putnam, 2000 and Norris, 1999). Questions about its validity have, however, been posed by findings from other studies that show results in contradiction with the CM hypotheses (e.g. Albright, 2009, Arzheimer, 2006, Marthaler, 2008, Dassonneville et al., 2012 and Van Deth, 2000) or offer alternative interpretations of changes in participatory trends (e.g. Berglund et al., 2005; Katz and Mair, 1995). This article aims to contribute to this debate by first addressing the conceptual framework of CM in order to better clarify the mechanisms at work, and then by empirically testing whether $\mathrm{CM}$ is, alone, able to explain membership in organizations.

The question key to this discussion is: why have participatory trends changed over time? Theories of social modernization argue that modernization and the transition to advanced industrial societies are processes that have brought about structural changes in various fields of society and politics. Yet, in terms of the inherently sociological theory of CM, the most significant and crucial change has been the sharp increase in education and information in the population, with a general improvement in citizens' resources and skills (Inglehart, 1977, pp. 295-297; Barnes and Kaase, 1979, p 524; Dalton, 2012). There are now better educated and more informed individuals than the past, and these individuals mostly belong to younger generations. According to advocates of this theory, one of the most relevant consequences of this compositional change in society is that these new individuals are more politically 
interested, but experience participation in politics and in civil society in radically different ways compared to older generations. As information costs decline, they tend to abandon hierarchical organizations such as political parties as they have become independent subjects. They tend to prefer participation in new types of socio-political organizations (hereafter activist associations) and bottom-up social movements, as well as participating in politics in more unconventional ways that allow them to deliberate thoughtfully on a wider set of political issues than the past ( Barnes and Kaase, 1979). Thanks to more educational resources in society, a process of top-down mobilization should have become ineffective and substituted by a new, mainly bottom-up, mobilization process. In short, taking the CM to its extreme implications would imply that, if educational levels had not increased in society, no major changes in the aggregate patterns of participation would have occurred.

The $\mathrm{CM}$ is obviously not the sole existing explanation in literature trying to account for patterns of participation and mobilization. However, explanations based on CM have a different focus than accounts based, for instance, on party mobilization. Although such explanations may be related in the real world, they are conceptually distinct and are often tested as alternative theories. Relevant literature is therefore divided on what plays the key role in participatory mobilization (e.g. Dalton, 2012; Zelle, 1995). While CM may not be a comprehensive explanatory theory of changes in participatory trends that excludes any other explanation, but just a contribution in terms of insight into the changed relationship between education/cognitive skills and types of mobilization over time, its advocates argue that it is the spread of education and skills in society that played a key role in the participatory change in the Western world (Inglehart, 1977; Dalton 2012).

Using Italy as a case-study, we first look at whether education is actually a key determinant of change at the aggregate level in different types of participation. We then critically explore the individual level mechanism of the thesis and how this fits the longitudinal evolution of participation. Far from challenging the validity of $\mathrm{CM}$ in its entirety, the emphasis of the study is on critically evaluating this theory in very specific aspects: a) we look at whether the relationship between education and different types of participation in Italy has changed and, if it did, whether it changed in the expected direction of $\mathrm{CM}$; b) the focus of this paper is 
restricted to participation as reflected by membership in different types of organizations ${ }^{1}$ : political parties and voluntary activist associations. ${ }^{2}$

Italy offers a suitable and interesting test case for CM in terms of participatory patterns, social modernization and data availability. This country has been characterized for a long time by political parties structured on the old model of the bureaucratic mass party, with relatively high levels of membership (Panebianco, 1982; Mair \& van Biezen, 2001) but, at least until the early 1960s, also by scant social associationism (Almond and Verba, 1963; Sani, 1980). This is to say that, for a long time, for many Italians participation in politics stemmed from their encapsulation in specific political subcultures, characterized by a partisan hold on many voluntary associations (Bartolini and Mair, 1990; Bartolini, 2000; Pizzorno, 1980). The participatory context of the early 1960s, however, started to change after Italy underwent a process of modernization and mass scholarization (1963-64), which was soon followed by an increase of participation in voluntary activist associations as well as in social movements. Although a sort of depoliticization of society has been in place since the late 1970s, it was only in the early 1990s with the end of the First Republic, when the political system was completely substituted following a series of scandals, that party participation dramatically dropped. Moreover, crucial for the aim of this study, modernization of Italian society happened relatively late compared to other Western countries. This provides an unprecedentedly large amount of data available for investigating the evolution of organizational participation over time, which accounts, at least partially, for the dramatic change of the Italian social context over almost a 40 year period.

In this paper, following a review of studies on the effects of education on participation and on the rise of CM theories, survey data are carefully harmonized and merged from different points in time since the early 1970s in order to cover as wider time period as possible (19722006). We investigate whether or not the crisis of participation in Italian mass parties, as well as the growth of activist organization participation can be satisfactorily explained by social change and, more specifically, by changes in the educational composition of society, as the $\mathrm{CM}$ posits. A first set of hypotheses looks at participatory dynamics at the aggregate level. A

\footnotetext{
${ }^{1}$ Social modernization and CM has been investigated by looking at different phenomena: electoral behaviour and volatility (Zelle, 1995), party membership and partisanship (Dalton, 2007, 2012; Barton and Doring, 1986) and social movements (Inglehart, 1990b), to name a few.

${ }^{2}$ Although the latter are often connected to social movements, participation in social movements is not directly included in the analysis here. Even though participation in social movements is one of the core CM effects on political participation, just as participation in organizational participation is, it is equally as vital to investigate each of these aspects in its own right.
} 
second set of hypotheses tests the CM mechanism that connects education and participation at the individual level, taking into account a moderator effect of social change on participatory trends. Findings show that the relationship between education and organizational participation in Italy has not changed in the direction expected by CM neither for political parties nor for activist associations.

\section{Education, system support and system criticism}

Early studies of political behaviour demonstrated that education has a direct positive impact on political and social participation, by enhancing citizens' psychological engagement and by providing them with the cultural instruments necessary to orientate themselves in the complex political world (Hyman and Wright, 1979, Van de Werfhorst and De Graaf, 2004 and Weakliem, 2002). On this line, the low levels of education in Italian society in the late 1950s were considered responsible for a lack of political skills, necessary to become a participatory citizen (e.g. Almond and Verba, 1963). Over the past 50 years, however, Italian society has expanded rapidly and significantly in terms of the distribution of educational levels in the population. In the 1991 census the ratio between the proportion of citizens that had completed secondary school level or more was up by 4 to 1 compared to 1961. In 2006, the educational levels of cohorts indicate that almost 30\% of people born between 1915 and 1924 have no school title, while more than half of the youngest cohorts have obtained a secondary school diploma and more than one in ten holds a university degree (Checchi et al., 2006). According to the early studies of participatory behaviour, a progressive increase in educational levels in society, such as the one that Italy experienced, should have led to averagely higher individual resources and skills, together with lower feelings of alienation from politics or society. This, in turn, should have increased citizens participation both in political and civil society associations (Verba et al., 1995). Yet, on the contrary, although participation has always interested a relatively small percentage of the population as in other Western countries, Italy has faced both a decrease of its relatively high aggregate levels of partisan conventional political participation and an increase of unconventional participation in activist associations over time.

This participatory trend evolution appears to be more in line with a new theory that started to gain popularity in the 1970s and that put forward the idea of a changed relationship between education and politics because of a compositional change of society (Inglehart, 1977, Inglehart, 1990a, Dalton, 1984 and Dalton, 2002). The term 'cognitive mobilization' was 
originally introduced by Inglehart to refer to 'the increasingly wide dissemination of the skills necessary to cope with an extensive political community', defined, within the broader context of modernization, as 'the very core of the process' of social mobilization (Inglehart, 1977, pp. 295-297). The author crucially incorporated CM within his framework and emphasized the change of values that allows individuals to increase their interest in politics, while becoming more autonomous from conventional hierarchical organizations and switching their preference towards unconventional forms of participation. $\mathrm{CM}$ claims that these changes are established in societies through a process of generational change. Since new generations are better educated and live in a society averagely more educated and richer in resources than the past, while becoming more politically interested, they also become less willing to accept a hierarchic and inclusive relation with politics that big bureaucratic organizations were able to offer them. For this reason new participatory demands arise (Inglehart, 1990a, pp. 335-370). Elaborating on Inglehart, Dalton (1984) utilized the concept of CM to attempt to explain partisan dealignment and declining levels of party identification in advanced industrial democracies ( Dalton, 2012, Dalton, 2013 and Dalton, 2014). He showed that higher levels of education in society lead to an increase in the number of party-independent citizens. Through education, more people, particularly among younger generations, are cognitively mobilized since they acquire the skills and resources that increase their ability to process political information and to make informed decisions, becoming less dependent on party cues. According to Dalton, the impact of increasing CM on politics is significant only when skills (i.e. education) are combined with a motivation (i.e. political interest) to apply these skills to politics. At the aggregate level, indeed, the amount of a new type of non-partisan citizens non-aligned but also better educated and politically sophisticated - seem to increase over time, increasing volatility in the electorate (Dalton, 2007 and Dalton, 2012).

Many other authors have incorporated the increasing cognitive skills of citizens into their studies in order to explore the changing relationship between citizens and political institutions. They found, for instance, that better education and more political competence are associated with being more critical towards the (conventional) political system, and that this in turn lead to the selection of other participation modalities (Fuchs and Klingemann, 1995, Pharr and Putnam, 2000 and Norris, 1999). Thus, what supporters of the CM theory propose is a multi-faceted universally valid approach originated by changes in educational levels of societies that is in sharp contrast to the past, when education was thought to promote rather than oppose system support. 


\section{Disentangling the mechanism of the $\mathrm{CM}$}

Despite the prevalence and crystallization of $\mathrm{CM}$ in comparative literature on political behaviour, there are in fact two major challenges to the unconditional adequacy of the theory. First, critical voices point to inconsistencies in the empirical support for the theory across studies. At the aggregate level, criticism of Dalton's model comes, for instance, from the empirical evidence that in some countries party attachment has not dropped much, and has even risen with society's modernization (Albright, 2009). But even when the aggregate development of participatory trends are consistent with what CM theory predicts, as in the evolution of the participatory trends in Italy, this does not necessarily prove that the main mechanism at work is the one assumed by it. CM theory is indeed based on some micro-level hypotheses, which have occasionally already been contested in literature (Barton and Doring, 1986, Arzheimer, 2006 and Huber et al., 2005). Van Deth (2000) for instance shows that cognitively mobilized people have lower, not higher, levels of political involvement because their scope of alternative action widens, and politics becomes less salient. The main criticism, however, comes from studies that prove that, at the individual level, highly sophisticated citizens are more, not less, likely to be partisan. Loss of party identity is indeed encountered among groups with low levels of education and political interest (Dassonneville et al., 2012, Arzheimer, 2006, Marthaler, 2008, Ohr et al., 2009, Albright, 2009 and Berglund et al., 2005). Although in the case of Germany this has been disproved by a later work by Dalton (2014), the issue remains controversial and casts doubts on CM as key causal mechanism for dealignment.

From a different perspective, Berglund et al. (2005) show that, by focussing on individual characteristics, the systemic relationship between contextual factors and party identification is not sufficiently accounted for, since party polarization may be responsible for a rise in partisanship. On the same line, Huber et al. (2005) hold that the characteristics of the political context, such as the nature of the competition between parties, may influence individuals propensity to form party attachment more than changes in the social structure do. Moreover, Zelle (1995) shows that volatility is determined by the degree of political dissatisfaction in the electorate, which is in turn likely to be caused by macro stimuli such as historic events, economic conditions, or the like, rather than by CM. Finally, change in participation has been explained as a logical consequence of the crisis in the structure of mass-bureaucratic parties in all Western countries (Katz and Mair, 1995; Ignazi, 2012). Although testing these 
alternative theories against each other could provide an explanation of which mechanism better accounts for change, in this article we specifically focus on the validity of $\mathrm{CM}$ hypotheses because of the importance of investigating the allegedly changed role of education for participation.

An important issue to address is that no clear enough indication is given in literature on what exactly the $\mathrm{CM}$ mechanism implies. The concept of $\mathrm{CM}$ has been used to investigate different political attitudes, values and phenomena, with slightly different definitions and operationalization each time, and to test different mechanisms. Yet, as the name of the theory recalls, the core notion of $\mathrm{CM}$ should be represented by its cognitive aspect and by the fact that a change in cognition is the basis for the self-mobilization of citizens. Thus, as other authors have also pointed out, CM refers first and foremost to the increase of skills (i.e. education) in society and should be operationalized as such. It can be argued whether involvement (e.g. interest) in politics could be considered part of CM or as a consequence of increased skills. But CM certainly does not include in its definition a change of values towards politics, or a decrease of party attachment, which may rather be considered as its expected consequences, but not as constitutional elements of the concept itself (see Berglund et al., 2005 and Barton and Doring, 1986). There is also the need to account more explicitly for the fact that $\mathrm{CM}$ operates at two different levels. At the macro level, modernization and mass scholarization have led to an increase of information and of educated citizens, changing a collective property of a society, which can be called its 'educational composition'. In turn, living in a society that is averagely more educated and has more cognitive resources than the past makes it easier for better-educated citizens to become more capable of independently processing the information they receive; and with less need for guidance from traditional parties, they start to feel at odds with the old rituals of participation. Thus, CM expects that the 'educational composition' of a society, that has changed towards better education over time, has a moderating effect on the relationship between individual levels of education (independent variable), and participation in a) political parties or b) activist associations (dependent variables). As a result of this, better-educated people, particularly of younger generations, should participate less in political parties and more in unconventional activist associations (Dalton, 1984 and Dalton, 2002). This is graphically displayed in Fig. 1. 


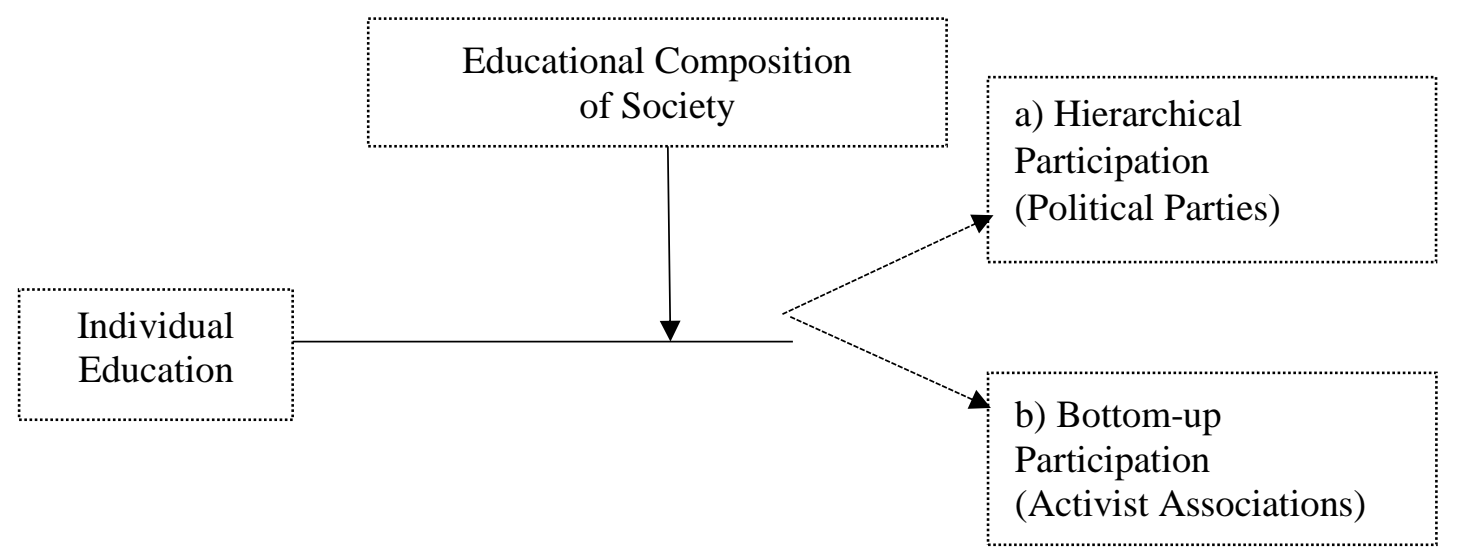

\section{Fig. 1. The CM mechanism}

As we show below, it is unquestionable that the level of education and information has been dramatically increasing in Italian society since the 1960s. Yet, CM conditions can only be considered satisfied when this rise of education has changed the relationship between being more educated and participating. More precisely, a) if there has been a change from a positive to a negative relationship between education and the participation in conventional politics over time and in younger, better educated generations; b) if the gap between the likelihood of participation in bottom-up activist associations of better-educated citizens, who participate more, and poorly educated citizens, who participates less, becomes larger over time and in younger, better educated generations. This study investigates whether this has been the case. If not, it becomes hard to justify the $\mathrm{CM}$ as a key mechanism at work to explain trends in organizational participations, and a need for expanding $\mathrm{CM}$ or to look for alternative explanations would arise.

\section{Research design and CM expectations}

This study relies on a merged file with five repeated cross-section studies of Italian National Election Studies (Itanes) and seven of Standard Eurobarometer (Eb), covering a period of almost 40 years (1972-2006). ${ }^{3}$ In order to test the CM mechanisms, the study proceeds in two steps. First, we test whether the CM thesis is a suitable explanation at the aggregate level by investigating the participatory trend over time, assuming constant educational level in society over the period studied. Then, we test the CM thesis by looking at the effects of education on participation at different levels of educational composition of society over time.

\footnotetext{
${ }^{3}$ Merged dataset (total N 18041): Itanes 1972, 1985, 1996, 2001, 2006; Standard Eb 1983(19); 1987(28); 1988(30); 1989(31); 1990(34); 1991(35); 1998(49); activist measures are present in 7 survey years.
} 
With the aim of reconstructing the country's participatory trends, organizational participation is chosen as the dependent variable. More specifically, we account for a) hierarchical political associations, defined here as political parties, and for b) any unconventional political organizations, defined here as voluntary single-issue activist associations, often related to social movements, ${ }^{4}$ such as associations dealing with environment, human rights, peace, and the like. Using survey sources that differ in the complexity of their measures, organizational participation is operationalized through the most common measure found across waves: membership in associations ((1) member; (0) not member). Measuring membership not only provides an extended series of participation measures, but also allows for homogenous questions to be asked across the surveys. Typically, the form in which membership is asked to respondents is the following: 'Are you a member of ... a political party? ... an (activist) association'.

The main independent variable considered is education. We look at education in two different ways: a) education at the individual level and b) the educational composition of society. Although we believe education to be at the core of the concept of cognitive mobilization, in order to make the results of our analyses comparable to previous operationalisations, Dalton (1984: 267) we construct an individual level index combining formal level of education of respondents (proxy for skills acquisition) with interest in politics (proxy for political involvement). Those scoring high on this index are those who are both highly educated and have the motivation to deal with the complexities of politics on their own. We refer to this index as education/interest (hereafter EI). ${ }^{6}$

In similar ways, educational composition of society is defined as the average level of education, information, cognitive skills and political interest in society at a certain point in time. Given the approximate linearity of education increase in society over the years and

\footnotetext{
${ }^{4}$ This is not necessarily the case for all organizations, but we rely on average features of these broad categorization types.

${ }^{5}$ Since the number and type of measured activist associations vary across waves, the focus is directed only on the association types that we can find in most surveys: environmental issues, animal rights associations and human rights associations. This may slightly reduce the scope of the analyses, but it has the advantage of covering an unprecedentedly long time-span to test the CM.

${ }^{6}$ Following Dalton (1984: 267), the index is an additive combination of education and general interest in politics. The respondent's educational level was coded according to the degree obtained by the respondent at the time of the interview, and to the correspondent average age in Italy: (1) low education (primary to lower secondary - Itanes; 6/15 y. - EB); (2) lower to higher secondary - - Itanes; 16/19 y. - EB); (3) university - Itanes; 20+ y. - EB). Political interest was coded: (1) not at all, (2) not much, (3) to some extent/a great deal). These two questions were added together to yield a six point index (2-6). All analyses have also been replicated using education only. Results go in similar directions as those shown in the text.
} 
across cohorts, the proxy of time is used and defined here in two distinct ways. First, we account for change over time of society as a whole, operationalized through survey-years ${ }^{7}$ (1972-2006 for party membership and 1983-2006 for activist associations). ${ }^{8}$ Second, we also account for changes in the educational composition of cohorts. We categorize the sample into seven generations, each covering a period of 10-years, by accounting also for the main political events occurring when respondents turned $18^{9}$ : Fascism (until 1943), the Cold War (1944-1953), the Italian Economic Boom (1954-1963), the Italian (and worldwide) mass demonstrations of Sixty-Eight (1964-1973), national Terrorism (1974-1983), Tangentopoli (i.e. Bribery City Scandal, 1984-1993) and Berlusconism (1994-2006) (see Corbetta and Ceccarini, 2010). The generation before Sixty-Eight (i.e. Economic Boom) is taken as a reference category because it is considered to be a crucial turning point in Italian politics. Not only is the cohort of Sixty-Eight, on average, much more educated than previous generations, but it was also socialized during a climate of great contestation of the conventional political system. It should then be the first to have experienced the CM mechanisms: better educated (and more politically interested) people belonging to this birth cohort (and later generations), should be less likely than past generations to participate in political parties and more likely to participate in activist associations.

Logistic regressions are used and the influence of the most important socio-demographic determinants of participation in Italy is also controlled for in the models. ${ }^{10}$ Including age, period and cohorts (APC) at the same time within the same model leads to the well-known issue of linear dependency (Glenn, 1976). We address it by using clustered standard error for the variable we exclude from the model (either period or cohorts). ${ }^{11}$

\footnotetext{
${ }^{7}$ Given the low number of time points used in the analyses, using objective educational aggregate levels would not provide better information. Both variables would provide qualitative rather than quantitative information (also making multilevel analysis not advisable). Since educational changes have been positively and linearly increasing over time, the best proxy to capture educational levels in a given year are survey years.

8 (1972), 1983, (1985), 1987, (1988, 1989), 1990, (1991), 1996, 1998, 2001, 2006.

${ }^{9}$ A cohort generally refers to a group of people of the same age (i.e. went to school in the same years). Citizens belonging to different cohorts, however, do not differ only in terms of their average educational levels, but also in terms of the social climate of their political socialization, which has crucial implications for their participatory behaviour (Mannheim, 1964; Corbetta, 2002; Bellucci and Segatti, 2010). Since in this study the effect of political events cannot be disentangled from the effects of the educational composition of society and that the participatory revolution of the 1960 s coincides with the educational revolution of society, political generations are accounted for when choosing cohorts.

${ }^{10}$ A dummy for survey type is introduced when looking at cohorts effects (Table 2 and Table $3 \mathrm{~b}$ ). All models have also been replicated using Itanes survey data only. Similar results than those shown are found.

${ }^{11}$ For a review of APC problem and proposed solutions see Neundord and Niemi's (2014) special issue in this journal. Although far from having reached a consensus on its validity (e.g. Bell and Jones, 2014), crossclassified multi-level approach is the most used approach to solve APC (Yang and Land, 2006 and Yang and Land, 2008). For the purpose of this article, given that we deal with one single country and we do not have
} 


\section{CM at the aggregate level}

With the aim of informing the discussion, educational trends over time as registered at Census (1951-2011) (Fig. 2), as well as aggregate participatory trends (1972-2006) of membership in different organizations as measured in the merged dataset, are displayed in graphic form (Fig. 3).

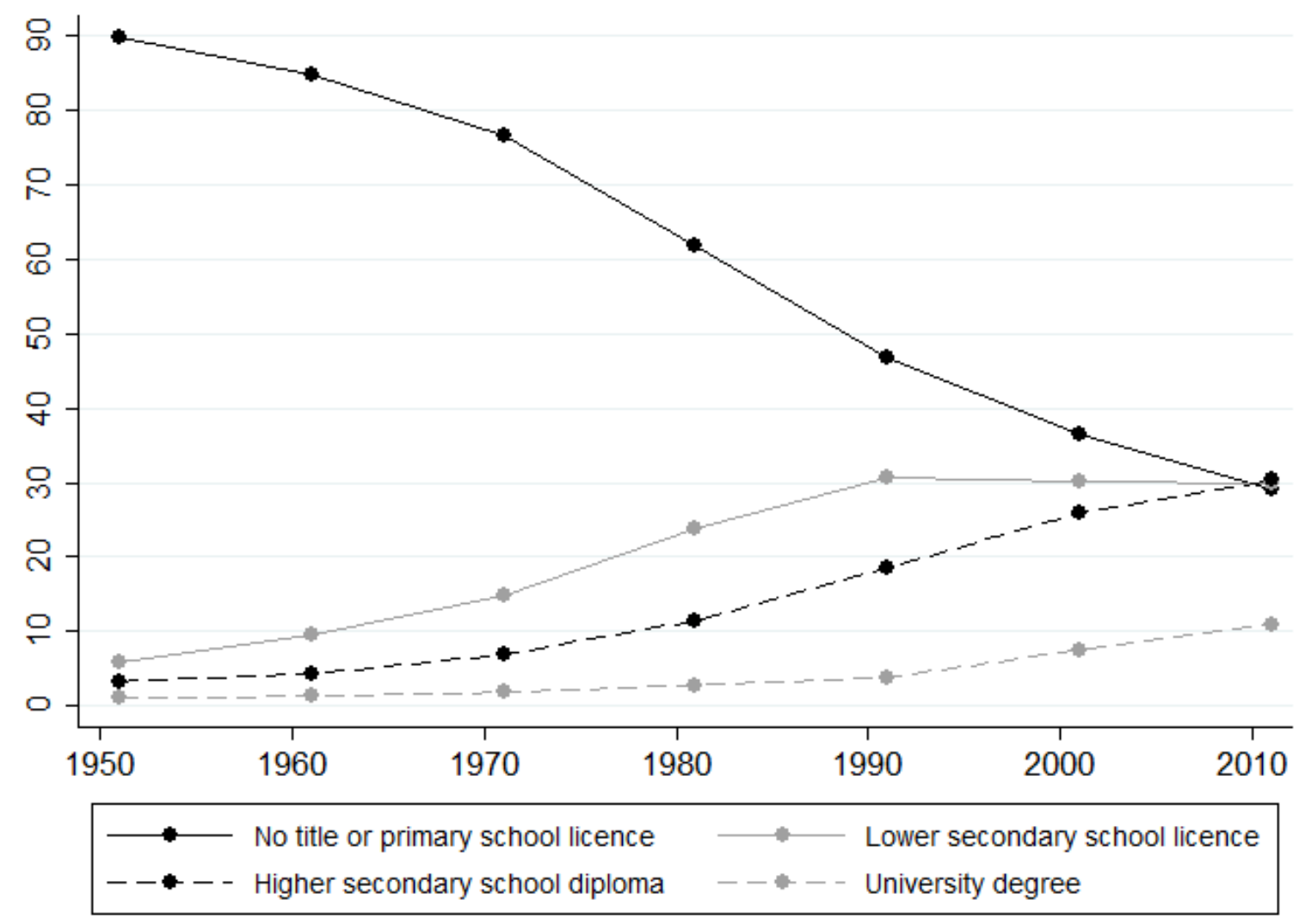

Fig. 2. Society Educational level (\%) over time, 1950e2010. Source: Censis. the same special issue. We get similar results than those shown when running hierarchical models. 


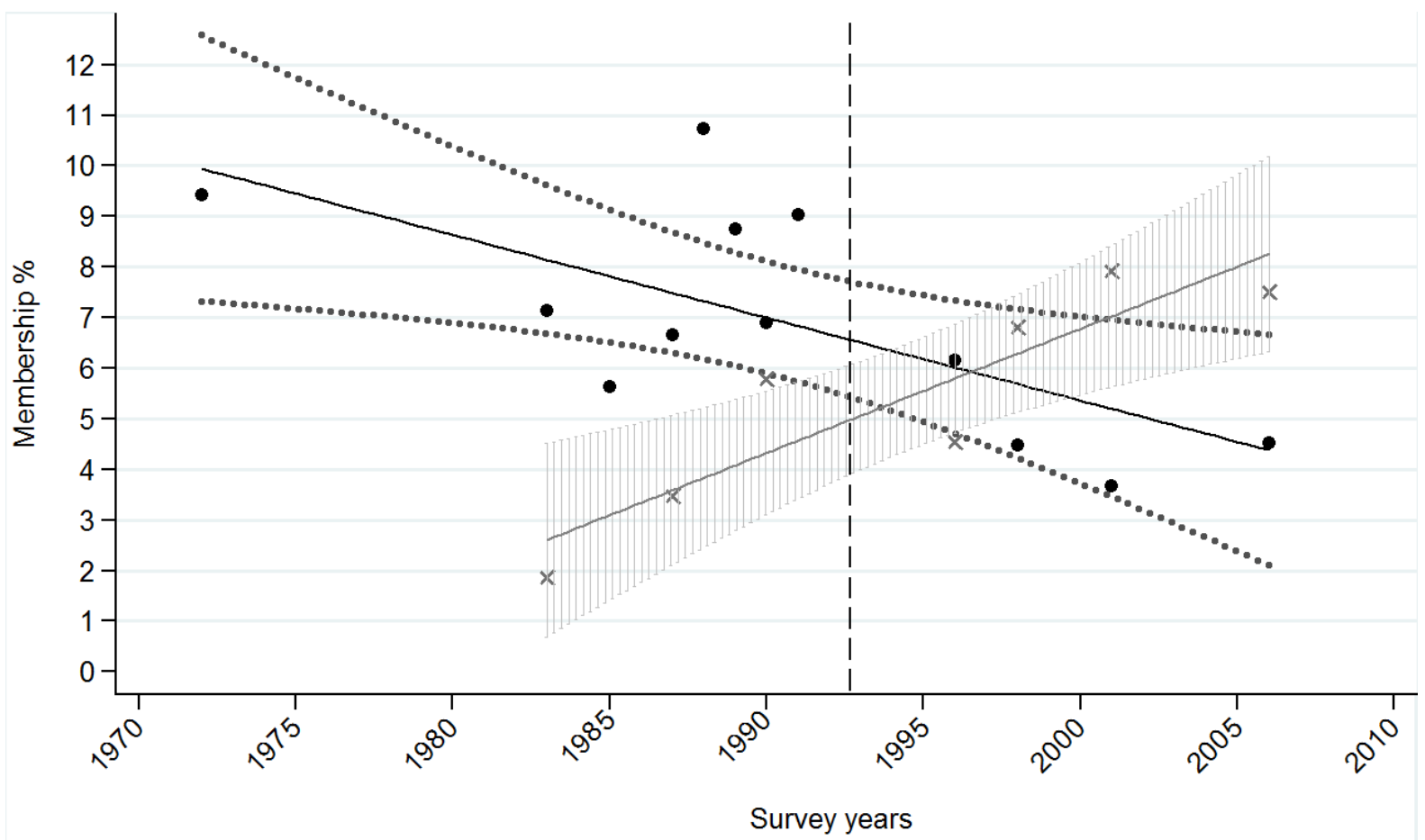

- Political Party $(95 \% \mathrm{Cl})$

$\times$ Activist Association $(95 \% \mathrm{Cl})$

Fig. 3. Membership (\%) in political parties and activist (environment/animal rights/human rights) associations over time, 1972-2006.

Note: Own elaboration of Itanes and EB data. Linear fit tendency lines indicate the participatory trend (and confidence intervals) over time. A vertical dotted line indicates the change from the First to the Second Italian Republic.

The general picture of Italian participatory phenomenon provided by the graph is roughly in line with CM expectations: 1) educational levels have consistently increased over time, moving from $6 \%$ of lower secondary degree to $30 \%$, from $3 \%$ of upper secondary degree to $30 \%$, and from 1 to $11 \%$ of university degree in 50 years; 2) averagely higher levels of education across society are associated with lower levels of party participation and higher levels of activist association participation. Yet, we see that participation in political parties in Italy was still quite high (around 9\%) during the whole of the First Republic, and started to decrease in the mid-1990s, dropping to around $4 \%$ in the first decade of the XXI century. Participation in activist associations has instead been constantly growing, moving from less than $2 \%$ in the early 1980 s to more than $7 \%$ in $2006 .{ }^{12}$

\footnotetext{
${ }^{12}$ Party Membership (in \%): 1972: 9.42, 1983: 7.13, 1985: 5.62, 1987: 6.65, 1988: 10.72, 1989: 8.75, 1990: 8.32, 1991: 9.03, 1996: 6.15, 1998: 4.47, 2001: 3.66; 2006: 4.51. Activist Membership (in \%): 1983: 1.86\%; 1987: 3.48; 1990: 5.78, 1996: 4.54; 1998: 6.81; 2001: 7.92; 2006: 7.51. The percentages of party membership
} 
The first step of the analysis is a reasoning at the aggregate level, which tests whether the educational composition of society is actually a key determinant of the change of participatory patterns. In the CM model it is assumed that if the educational composition of society had remained constant over time, that is if the Italian society of 2006 were on average equally as educated as the society of the early 1970s, participation in political parties as well as in activist associations would have stayed constant over the years (H1a). In the same way, it is assumed that if political generations were on average equally educated, younger generations would participate in political and activist associations as much as older generations (H1b). Thus, after controlling for the distribution of EI over time (H1a) and across political cohorts (H1b), overall participation rates in both hierarchical and bottom-up associations in Italian society, over time, should become (almost) constant (H1a) and the generation of Sixty-Eight and younger generations ought to participate in associations (almost) as much as previous generations (H1b). This is empirically tested by running logistic regressions using association membership as the dependent variable and survey years (H1a) or political cohorts (H1b) as the main independent variables in a first baseline model while controlling also for levels of education and political interest (i.e. holding EI constant) in a second model. We then report the predicted probabilities of participation in different association type for average levels of education (and political interest). ${ }^{13}$

Over time odds ratio of party membership (A) and activist associations (B) with (1) and without (2) the influence of EI are shown in Table 1. Odds ratio indicates the probability of an event occurring divided by the probability of the same event not occurring. Controlling for other variables in the baseline model, the odds of becoming a party member after a unit increase in survey years tend to be significantly lower (0.97). And these are even lower when levels of EI are controlled for (0.96). This means that, instead of becoming constant (i.e. not significant) as expected by CM (H1a), party membership is significantly lower over time (A1), and is even lower after controlling for average levels of education (and political interest) in society (A2). In fact, looking at predicted probabilities of becoming a party member for average levels of $E I$ over time, we can see there is a decline from $11.6 \%$ in 1972 to $2.7 \%$ in 2006 . In the same way, the odds of becoming a member of an activist association

reported by different surveys have been validated with figures officially reported by the parties themselves (van Biezen, Mair and Poguntke, 2012). The two measures report very similar membership levels (Pearson correlation 0.97 for 4 points in time in different decades).

${ }^{13}$ It is not possible to run the analysis at the aggregate level because there are not enough cases. Analyses have been replicated with the variable education harmonized accounting for the fact that mass scholarization changed the social and economic significance of Italian educational qualifications before and after the reform law of 1963-64 (Corbetta and Ceccarini, 2010). Results are not substantively different to those shown. 
are significantly higher every year by $7 \%$ in both models (B1 and B2). Whilst predicted probabilities of becoming an activist organization member for average levels of EI move from $2.1 \%$ in 1983 to $9.3 \%$ in 2006 .

Table 1. Odds Ratio of Membership in Political Parties (A) and Activist Associations (B) over Years after controlling for the Education/Interest Index, 1972-2006 - H1a

\begin{tabular}{lllll}
\hline Hla & \multicolumn{2}{l}{ A. Political Parties } & \multicolumn{2}{l}{ B. Activist Associations } \\
\hline Survey Years & $0.97(0.01)^{* * *}$ & $0.96(0.01)^{* * *}$ & $1.07(0.01)^{* * *}$ & $1.07(0.01)^{* * *}$ \\
Education/Interest & & & & \\
index (EI) (ref: low) & & $1.89(0.07)^{* * *}$ & - & $1.52(0.04)^{* * *}$ \\
Gender (ref: female) & $0.31(0.04)^{* * *}$ & $0.39(0.04)^{* * *}$ & $1.02(0.10)$ & $1.18(0.12)$ \\
Age (centred) & $1.00(0.01)$ & $1.01(0.01)^{*}$ & $0.99(0.00)^{*}$ & $1.00(0.00)$ \\
Geo-political Areas & $($ ref: North-West) & & $($ ref: North) & \\
North-east & $0.90(0.11)$ & $0.91(0.12)$ & - & - \\
Red belt & $1.58(0.15)^{* * *}$ & $1.57(0.15)^{* * *}$ & - & - \\
Centre & $1.23(0.07)^{* * *}$ & $1.13(0.05)^{* *}$ & $0.80(0.12)$ & $0.78(0.12)$ \\
South & $1.21(0.11)^{*}$ & $1.25(0.11)^{* *}$ & $0.77(0.06)^{* *}$ & $0.80(0.06)^{* *}$ \\
Survey (ref: Itanes) & & & & $1.17(0.21)$ \\
Standard EB & $1.34(0.11)^{* * *}$ & $0.99(0.09)$ & $1.27(0.20)$ & $7.28 \mathrm{e}-61$ \\
Constant & $1.16 \mathrm{e}+22$ & $6.25 \mathrm{e}+37$ & $7.00 \mathrm{e}-57$ & $(2.01 \mathrm{e}-59)^{* * *}$ \\
\hline Log PseudoL & $(1.56 \mathrm{e}+23)^{* * *}$ & $(7.58 \mathrm{e}+38)^{* * *}$ & $(1.82 \mathrm{e}-55)^{* * *}$ & -2461.00 \\
N & -4072.10 & -3814.94 & -2533.11 & 11387 \\
\hline
\end{tabular}

Note: Own elaboration of Itanes and EB data. Odds Ratios are displayed. Clustered standard error for political cohorts in parenthesis. ${ }^{\mathrm{a}} \mathrm{p} \leq .10 ; * \mathrm{p} \leq .05 ; * * \mathrm{p} \leq .01 ; * * * \mathrm{p} \leq .001$

Moving to the next hypothesis, changes over time are explored in greater detail, by looking at different political cohorts. Table 2 shows the odds ratio of party membership (A), and activist associations (B) over cohorts. Also in this case, no constant trends (H1b) are found in moving from the baseline model (1) to the model in which $E I$ is controlled for (2). The odds ratios for party membership are increasingly lower than the reference category (i.e. Economic Boom) after the generation of Sixty Eight in the baseline model (A1) and (even more so) starting from the generation of Sixty Eight after (A2) controlling for EI. Whereas, they are increasingly and significantly higher for activist association membership starting from the generation of Sixty-Eight in the baseline model (B1) and (even more so) after it when controlling for $E I$ (B2). Predicted probabilities for average EI levels move from $14.5 \%$ of the 
oldest generation to $1 \%$ of the youngest generation in the case of party members, and from $1.1 \%$ to $17.6 \%$ in the case of activist organization membership.

Table 2. Odds Ratio of Membership in Political Parties (A) and Activist Associations (B) over Political Cohorts after controlling for the Education/Interest Index - H1b

\begin{tabular}{|c|c|c|c|c|}
\hline \multirow{2}{*}{$\frac{H 1 b}{\text { Political Cohorts }}$} & \multicolumn{2}{|l|}{ A. Political Parties } & \multicolumn{2}{|c|}{ B. Activist Associations } \\
\hline & \multicolumn{4}{|c|}{ (ref: 3. Economic Boom) } \\
\hline 1.Fascism & $1.21(0.17)$ & $1.83(0.30)^{* * *}$ & $0.26(0.10) * * *$ & $0.26(0.11)^{* * *}$ \\
\hline 2.Cold war & $0.98(0.10)$ & $1.28(0.12)^{* *}$ & $0.73(0.12)^{\mathrm{a}}$ & $0.78(0.14)$ \\
\hline 4.Sixty-eight & $0.88(0.11)$ & $0.69(0.09)^{* *}$ & $1.38(0.26)^{\mathrm{a}}$ & $1.30(0.23)$ \\
\hline 5.Terrorism & $0.48(0.09)^{* * *}$ & $0.33(0.07) * * *$ & $2.36(0.78)^{* *}$ & $2.38(0.81)^{*}$ \\
\hline 6.Tangentopoli & $0.25(0.06)^{* * *}$ & $0.15(0.04)^{* * *}$ & $3.66(1.66)^{* *}$ & $3.83(1.85)^{* *}$ \\
\hline 7.Berlusconism & $0.16(0.06)^{* * *}$ & $0.10(0.04) * * *$ & $4.80(3.23)^{*}$ & $5.45(4.09) *$ \\
\hline $\begin{array}{l}\text { Education/Interest } \\
\text { index (EI) (ref: low) }\end{array}$ & - & $1.84(0.09) * * *$ & - & $1.52(0.06)^{* * *}$ \\
\hline Gender (ref: female) & $0.31(0.03) * * *$ & $0.39(0.03) * * *$ & $1.02(0.07)$ & $1.18(0.08)^{* *}$ \\
\hline Age (centred) & $0.98(0.01)^{* *}$ & $0.97(0.00)^{* * *}$ & $1.04(0.01)^{* *}$ & $1.04(0.02)^{* *}$ \\
\hline Geo-political Areas & (ref: North-West) & & (ref: North) & \\
\hline North-east & $0.90(0.08)$ & $0.91(0.08)$ & & \\
\hline Red belt & $1.58(0.18) * * *$ & $1.58(0.17)^{* * *}$ & & \\
\hline Centre & $1.23(0.14)$ & $1.14(0.13)$ & $0.80(0.05)^{* * *}$ & $0.78(0.06)^{* * *}$ \\
\hline South & $1.22(0.13)$ & $1.26(0.11)^{* *}$ & $0.78(0.08)^{* *}$ & $0.81(0.10)^{\mathrm{a}}$ \\
\hline \multicolumn{5}{|l|}{ Survey (ref: Itanes) } \\
\hline Standard EB & $1.30(0.17)^{*}$ & $0.96(0.16)$ & $1.03(0.24)$ & $0.94(0.27)$ \\
\hline Constant & $0.12(0.02) * * *$ & $0.02(0.00)^{* * *}$ & $0.04(0.01)^{* * *}$ & $0.01(0.00)^{* * *}$ \\
\hline Log PseudoL & -4039.60 & -3797.84 & -2538.66 & -2466.63 \\
\hline $\mathrm{N}$ & 18127 & 18041 & 11427 & 11387 \\
\hline
\end{tabular}

Note: Own elaboration of Itanes and EB data. Odds Ratios are displayed. Clustered standard error for surveyyears in parenthesis. ${ }^{a} \mathrm{p} \leq .10 ; * \mathrm{p} \leq .05 ; * * \mathrm{p} \leq .01 ; * * * \mathrm{p} \leq .001$

Thus, on the whole, the findings of both hypotheses $\mathrm{H} 1 \mathrm{a}$ and $\mathrm{H} 1 \mathrm{~b}$ seem not to corroborate the $\mathrm{CM}$ thesis of education as a key determinant of change. If the average levels of education (and political interest) in society had stayed constant over the years and across cohorts, participation in political parties would still have become lower over time, while participation in activist associations would still have grown over time. In other words, there is no evidence that the change in the educational composition of Italian society has been a key determinant influencing participatory changes, as expected by $\mathrm{CM}$. This is not (yet) to say that the mechanism at work in the relationship between education and participation is not going in the direction claimed by CM. It may be, as the CM thesis claims, that people with high levels of EI participate less in political parties and more in activist associations compared to the past. 
However, it could be that it is mainly people with low levels of EI that are participating less in political parties and more in activist associations compared to the past. It could also be that everybody participates less in political parties and more in activist associations compared to the past, but the relationship between people with high and low levels of EI remains unchanged. These three mechanisms are all compatible with the results of the previous hypotheses, because in both cases party participation drops and activist participation increases.

\section{6. $\mathrm{CM}$ at the individual level}

In order to know which mechanism models the relationship between the education/interest index and levels of participation we need to take a closer look at it by investigating the moderating effect that society's educational composition as a contextual property has on the individual level relationship between EI and participation. Moderation is characterized statistically as an interaction between the variables of interest. The CM thesis assumes that, when the educational composition of society changes, the change of participatory behaviour should be particularly pronounced among well-educated citizens. Thus, with higher average levels of education in society; a) well-educated (and politically interested) citizens should be less willing to participate in political parties than poorly educated citizens are (negative relationship of education); and b) they should be more attracted to join activist associations than poorly educated citizens are, compared to the past (increasingly larger positive gap) (H2a). Furthermore, the CM thesis also posits that it is particularly the well-educated (and politically interested) citizens belonging to younger generations that should have changed their participatory behaviour compared to older generations. As besides experiencing general higher levels of education in society, the well-educated members of younger generations also belong to better-educated cohorts. Consequentially, the likelihood of the cognitively mobilized (high educated and politically interested) members of younger (better-educated) generations joining political parties ought to be lower than the not cognitively mobilized. Whereas, for joining activist associations not only should this likelihood be higher for the well-educated (and politically interested) but also the likelihood gap between the two groups should be larger in younger generations $(\mathrm{H} 2 \mathrm{~b})$. 
Table 3. Model with Interaction between EI and Years on Political Party (A) and Activist Association (B) Membership-H2a \& H2b (Log Odds)

\begin{tabular}{|c|c|c|c|c|c|}
\hline$H 2 a$ & $\begin{array}{l}\text { A. Political } \\
\text { Parties }\end{array}$ & $\begin{array}{l}\text { B. Activist } \\
\text { Associations }\end{array}$ & $H 2 b$ & $\begin{array}{l}\text { A. Political } \\
\text { Parties }\end{array}$ & $\begin{array}{l}\text { B. Activist } \\
\text { Associations }\end{array}$ \\
\hline $\begin{array}{l}\text { Survey } \\
\text { Years }\end{array}$ & (ref: 1972) & (ref: 1983) & Political Cohorts & \multicolumn{2}{|c|}{ (ref: 3. Econ. Boom) } \\
\hline 1983 & $-0.44(0.27)$ & - & 1. Fascism & $0.33(0.14)^{*}$ & $-1.24(0.39)^{* * *}$ \\
\hline 1985 & $-0.61(0.10)^{* * *}$ & - & 2. Cold War & $0.11(0.09)$ & $-0.33(0.13)^{*}$ \\
\hline 1987 & $-0.61(0.33)^{\mathrm{a}}$ & $0.46(0.21)^{*}$ & 4. Sixty-Eight & $-0.28(0.23)^{*}$ & $0.37(0.13)^{* *}$ \\
\hline 1988 & $-0.00(0.25)$ & - & 5. Terrorism & $-0.97(0.26)^{* * *}$ & $0.99(0.21)^{* * *}$ \\
\hline 1989 & $-0.38(0.24)$ & - & 6. Tangentopoli & $-1.73(0.21)^{* * *}$ & $1.45(0.29) * * *$ \\
\hline 1990 & $-0.13(0.25)$ & $1.02(0.26)^{* * *}$ & 7. Berlusconism & $-2.05(0.30)^{* * *}$ & $1.79(0.46)^{* * *}$ \\
\hline 1991 & $-0.43(0.23)^{\mathrm{a}}$ & - & & & \\
\hline 1996 & $-0.76(0.17)^{* * *}$ & $0.88(0.23)^{* * *}$ & & & \\
\hline 1998 & $-1.29(0.27)^{* * *}$ & $1.19(0.21)^{* * *}$ & & & \\
\hline 2001 & $-1.29(0.20)^{* * *}$ & $1.57(0.19)^{* * *}$ & & & \\
\hline 2006 & $-1.12(0.25)^{* * *}$ & $1.50(0.20)^{* * *}$ & & & \\
\hline $\begin{array}{l}\text { EI index } \\
\text { (ref: low) }\end{array}$ & $1.11(0.39)^{* *}$ & $1.22(0.67)^{\mathrm{a}}$ & & $1.04(0.15)^{* * *}$ & $1.28(0.33)^{* * *}$ \\
\hline EI \# Years & & & EI \# Cohorts & & \\
\hline \# 1983 & $0.35(0.55)$ & - & \# Fascism & $0.01(0.24)$ & $-0.70(0.99)$ \\
\hline \# 1985 & $-0.12(0.29)$ & - & \# Cold War & $-0.30(0.27)$ & $0.39(0.37)$ \\
\hline \# 1987 & $-0.10(0.48)$ & $-0.10(0.80)$ & \# Sixty-Eight & $0.28(0.19)$ & $-0.33(0.40)$ \\
\hline \# 1988 & $0.20(0.49)$ & - & \# Terrorism & $0.42(0.19)^{*}$ & $-0.46(0.41)$ \\
\hline \# 1989 & $0.11(0.42)$ & - & \# Tangentop & $0.63(0.19)^{* * *}$ & $-0.39(0.26)$ \\
\hline \# 1990 & $-0.47(0.61)$ & $0.06(0.68)$ & \# Berluscon & $0.57(0.45)$ & $-0.38(0.51)$ \\
\hline \# 1991 & $-0.25(0.29)$ & - & & & \\
\hline \# 1996 & $0.25(0.35)$ & $-0.34(0.71)$ & & & \\
\hline \# 1998 & $0.65(0.53)$ & $0.02(0.71)$ & & & \\
\hline \# 2001 & $0.56(0.29)^{*}$ & $-0.38(0.68)$ & & & \\
\hline \# 2006 & $0.91(0.38)^{*}$ & $-0.21(0.56)$ & & & \\
\hline $\begin{array}{l}\text { Gender } \\
\text { (ref: female) }\end{array}$ & $-1.07(0.13)^{* * *}$ & $0.10(0.10)$ & & $-1.07(0.09) * * *$ & $0.11(0.06)^{\mathrm{a}}$ \\
\hline Age(centred) & $0.01(0.01)$ & $-0.01(0.00)^{*}$ & & $-0.02(0.01)^{* * *}$ & $0.04(0.01)^{* * *}$ \\
\hline \multicolumn{6}{|c|}{$\begin{array}{l}\text { Geo-political } \\
\text { Areas (ref: North-West/North) }\end{array}$} \\
\hline North East & $-0.97(0.13)$ & - & & $-0.10(0.09)$ & - \\
\hline Red Belt & $0.48(0.09)^{* * *}$ & - & & $0.47(0.11)^{* * *}$ & - \\
\hline Centre & $0.17(0.05)^{* * *}$ & $-0.23(0.15)$ & & $0.17(0.12)$ & $-0.23(0.08) * *$ \\
\hline South & $0.20(0.09)^{*}$ & $-0.24(0.07)^{* * *}$ & & $0.21(0.09)^{*}$ & $-0.23(0.11)^{*}$ \\
\hline Constant & $-2.04(0.21)^{* * *}$ & $-4.02(0.19)^{* * *}$ & & $-1.07(0.09)^{* * *}$ & $-3.44(0.20)^{* * *}$ \\
\hline $\begin{array}{l}\text { Log PseudoL } \\
\mathrm{N}\end{array}$ & $\begin{array}{l}-3907.37 \\
18041\end{array}$ & $\begin{array}{l}-2468.90 \\
11387\end{array}$ & Log PseudoL & $\begin{array}{l}-3912.39 \\
18041\end{array}$ & $\begin{array}{l}-2483.93 \\
11387\end{array}$ \\
\hline
\end{tabular}


Note: Own elaboration of Itanes and EB data. Log Odds are displayed. Clustered standard error in parenthesis (for cohorts in $\mathrm{H} 2 \mathrm{a}$ and for survey-years in $\mathrm{H} 2 \mathrm{~b}$ ). ${ }^{\mathrm{a}} \mathrm{p} \leq .10 ;{ }^{*} \mathrm{p} \leq .05 ;{ }^{* *} \mathrm{p} \leq .01 ; * * * \mathrm{p} \leq .001$

As before, logistic regressions are run using association membership as the dependent variable, and average educational society level, expressed as survey years (H2a) or political cohorts $(\mathrm{H} 2 \mathrm{~b})$ together with a dummy variable for the individual level $E I$ index ${ }^{14}$ as the main independent variables. This time, however, an interaction between time (survey years or political cohorts) and EI is added. Table 3 displays the estimated coefficients (log odds) of the model for participation in political parties (A) and activist associations (B).
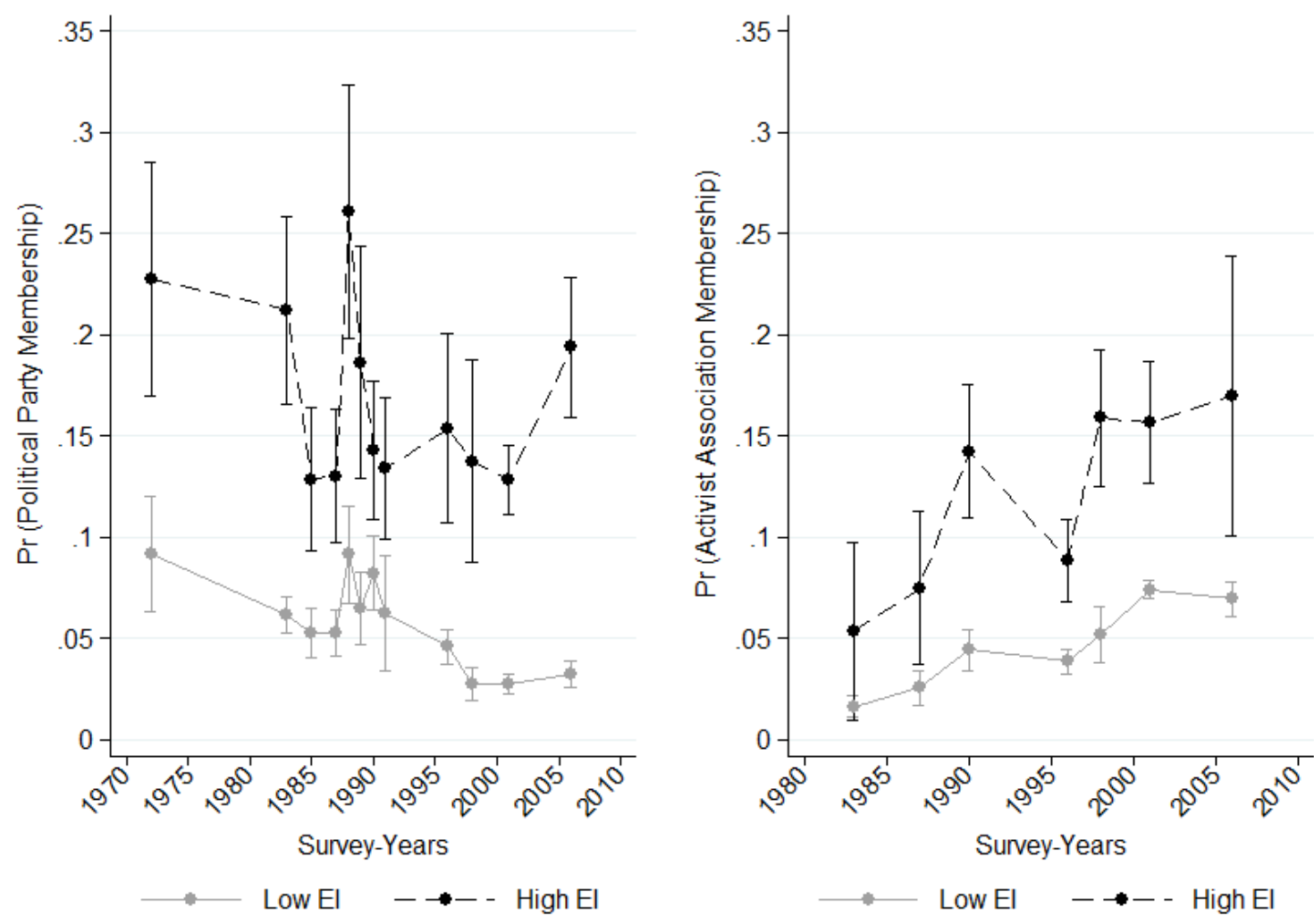

Fig. 4. Predictive margins of CM for political party and activist association membership, 1972-2006-H2a.

We first look at the two models on the left of Table 3 (H2a). As we can see, in both cases, the effect of EI in the reference year is positive and significant. However, only few interactions coefficients between EI and survey years are significant and only for the model of party

\footnotetext{
${ }^{14} \mathrm{EI}$ is an index that combines education and political interest as explained above. Values of 4 or less are treated as low cognitive mobilization.
} 
membership. Results are illustrated more directly by looking visually at predictive margins. Fig. 4 shows that, although everybody tends to be less likely to become a party member over time, well-educated (and politically interested) people tend to be more likely to participate than citizens with low EI. In the past as in more recent years, people with higher education and political interest tend to have (similarly) higher chances of becoming a party member within each survey year than people with low EI. If anything can be noticed from the figure, it is that this difference tends to be larger in the last decade. Whilst in terms of activists associations, the well-educated tend to participate more. However, statistically, the gap between the two educational levels remains almost constant over time, despite society being averagely more scholarized.

Overall, this suggests that the effect of EI on party participation remains positive and predominantly constant over time for membership in both association types. This contradicts the $\mathrm{CM}$ because, in the case of party membership, the effect of education (and political interest) does not become negative in more recent years, while in the case of activist membership the likelihood gap of participation between high and low EI does not become higher over time. Thus, in both cases, the CM expectations are not met.

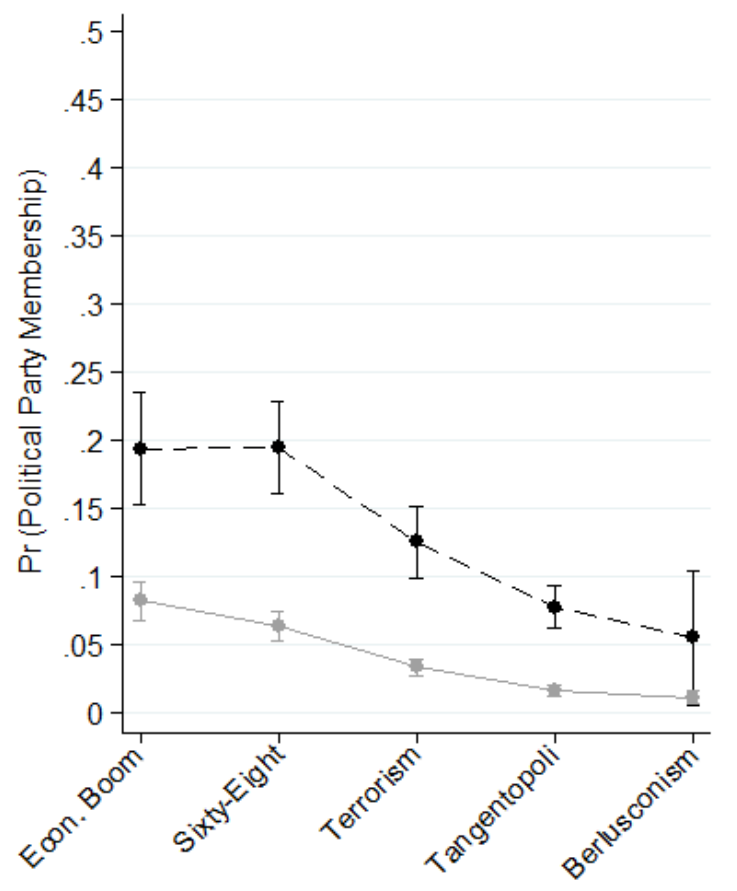

Socialization Cohorts

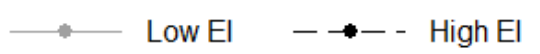

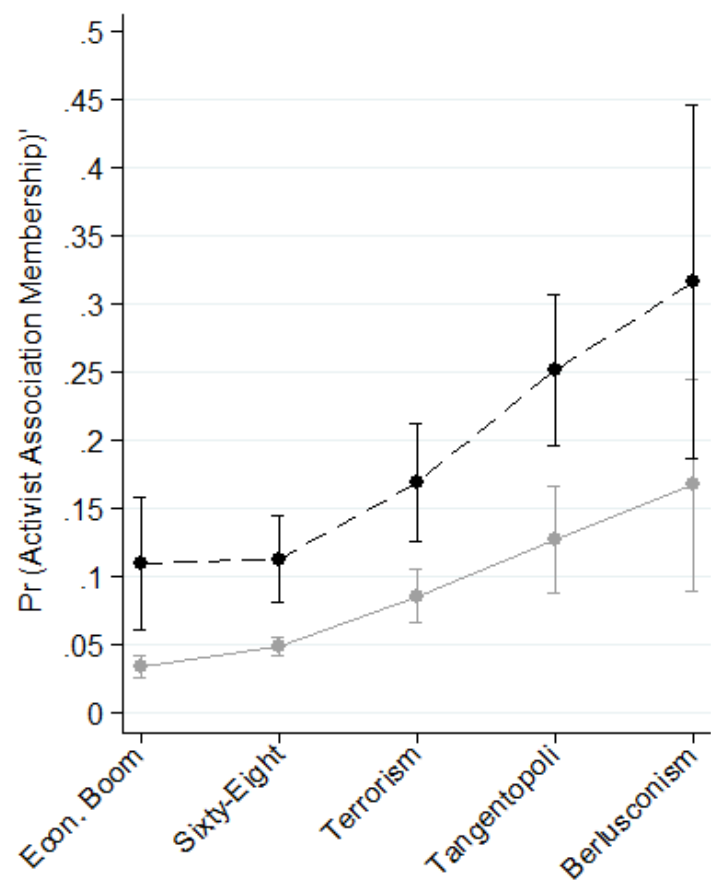

Socialization Cohorts

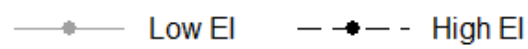


Fig. 5 Predictive margins of CM for political party and activist association membership, cohorts $-\mathrm{H} 2 \mathrm{~b}$.

We now move to the two models on the right of Table $3(\mathrm{H} 2 \mathrm{~b})$. Also in this case the effect of EI in the reference cohort is positive and significant, whereas only a few interactions coefficients between EI and cohorts are significant and only for the model of party membership. Also in this case, results are illustrated more directly by looking visually at predictive margins for the cohorts we are interested in (i.e. starting with the cohort of Economic Boom) (Fig. 5). Even considering the possible exception of the generation of Berlusconism and that on the whole citizens belonging to younger generations tend to be less likely to become party members than the generation of Economic Boom, the better educated (and politically interested) citizens tend to be more, not less likely to participate than people with low EI. This gap remains almost constant with younger generations (estimated coefficients suggests it might even be larger in two of the younger cohorts). Whilst in terms of activists associations, well-educated (and politically interested) citizens tend to participate more than citizens with low EI and the gap is similar over generations. If anything can be noticed from the figure it is that this gap is minimal and even seems to be smaller in younger generations. In order for the CM expectation to be met, however, this gap should be larger compared to older generations.

Once again, this suggest that, overall, the effect of EI on party participation remains positive and predominantly constant for each generation after the generation of Economic Boom for membership in both association types. This contradicts the CM thesis because, in the case of party membership, the effect of education (and political interest) does not become negative in younger generations, while in the case of activist membership the likelihood gap of participation between high and low EI does not become larger with younger generations. These results further suggest that factors other than mass scholarization are also responsible for changing participatory trends.

\section{Discussion and conclusion}

The aim of this study was to explore if the process of cognitive mobilization has played a key role in shaping organizational participatory trends in traditional political parties and in activist associations in Western Europe, taking Italy as a case-study (Inglehart, 1977, Inglehart, 1990a, Dalton, 1984 and Dalton, 2002). It has been shown that, at the aggregate level, CM seems not to be a key explanation at work for declining levels of party membership 
and for increasing levels of activist association membership. Also, looking at the individual level relationship of education (and political interest) with different types of organizational participation, and accounting for the effect of the change in the educational composition of society, CM expectations have not been met in either type of organization. Political party membership, although never extremely high in absolute terms, tend to be lower for all educational levels, but the effect of education remains positive and constant overall over time on the decision to join parties (H2a). If anything, in the last decade there might be an indication of a greater decrease for the lower educated than for the higher educated (and more politically interested) citizens. Moreover, better-educated (and more politically interested) citizens of young cohorts still participate more in political parties than their poorly educated counterparts $(\mathrm{H} 2 \mathrm{~b})$. This contradicts $\mathrm{CM}$ expectations in terms of changing educational effects (from positive to negative) on party participation. For activist associations, since the 1980s (H2a) and after the generation of Economic Boom (H2b), participation is higher for the better educated (and politically interested) than for the poorly educated. However, the likelihood gap of becoming a member of these organizations between people with high and low educational levels does not become larger over time or with belonging to younger generations. Rather it tends to stay (statistically) constant. In conclusion, it is still the poorly educated of younger generations that participate less in political parties, not the better educated as the CM model posits. Thus, the positive effect and larger presence of education in society appears to stem rather than fuel the general trend of decreasing participation in parties. Simultaneously, as in the past, education is a positive predictor for membership in activist associations. However, increasing trends of participation do not seem to be related to the larger presence of education in society, since both the poorly and well-educated citizens participate more than the past. This leads us to conclude that $\mathrm{CM}$ is not the key explanatory mechanism at work.

After having assessed data reliability and validity, and replicated models using more conservative tools, it can reasonably be stated that a robust pattern seems to exist in the data in the direction of the results presented. This does not necessarily imply any grand conclusions on CM. As mentioned, this study investigates only specific aspects of the theory, namely the changed relationship between education and participation due to changing educational levels in society, in a specific participatory context: the organizational participation in political parties and activist associations in Italy. Although unconventional modes of participation and social movements are related to the latter, for good reasons, they 
have not been the focus of this study and no conclusions can be drawn about them. This study nonetheless has a few major implications.

The first is that the central tenants of the CM thesis need careful re-examination and further clarification in literature of the mechanisms through which it should operate. This study has presented an initial contribution in this respect. The second is that the relationship between education and organizational participation seems not to have changed at the individual level: education is still a predictor of more participation in political parties and in activist associations, but in the latter case no more than it used to be in the past. The third is that serious reflection on the universal adequacy of $\mathrm{CM}$ as a key mechanism at work is required, together with a widening of perspectives on $\mathrm{CM}$ in different directions. As we mentioned previously, while CM may not be a comprehensive explanatory theory of changes in participatory trends that excludes any other explanation, its advocates argue that it is the spread of education and skills in society that played a key role in the participatory change in the Western world. What this study's results show is not only that CM, if at work in organizational participation in Italy, it is not the key mechanism, but also that mass-education has actually been responsible for hampering the decline of party membership while only marginally affecting the increase of membership in activist associations. Further studies should explore whether this is also the case in other Western countries.

Although suggesting the directions in which CM literature should expand is beyond the scope of this article, it is worth illustrating the changes that the Italian society went through besides mass scholarization. This could set the ground for "tentative" hypotheses to be tested in future research. One way to look at the results is for instance by applying Converse's (1969) ideas on partisan stability to party membership: Partisanship is acquired through socialization, and partisan stability tends to accumulate over the adult years. A drop in party participation in a country like Italy, which has suffered serious disruptions to the party system, might be due to the fact that time is needed in order for membership in new parties to increase to similar levels as before the disruption. Therefore, it is possible that CM does work in this country, but its effect is swamped by the (temporary) weakening of mobilization of the base that follows a major disruption to the political system. Yet, it needs to be noted that similar participatory trends to those observed in Italy seem to be affecting other advanced industrial democracies that have not undergone drastic changes in the political system (van Biezen et al., 2012). 
According to a different literature the main cause of decline in participation in political parties, in Italy as in other Western Democracies, has been the end in mobilization from above, and the slow but constant collapse of political subculture of society that resulted in increasing the costs of joining a party (see Katz and Mair, 1995 and Mannheimer and Sani, 1987). Italian political participation has historically been rooted in the habituation of being encapsulated in territorial political subcultures and mobilized from above. First Republic parties (before the 1990s) were based on mass cleavage models that allowed lower educated citizens to be mobilized (Pasquino, 2001 and Gunther and Diamond, 2003). Following a trend in Western countries, with the modernization of society and of political parties, old mass parties' gradually assumed the characteristics of a cartel party, as they became increasingly professional and centralized no longer requiring mass mobilization (Katz and Mair, 1995; Dalton and Wattenberg, 2000 and Ignazi, 2012). In this sense, in line with previous works on "attitudinal partisanship" (Bartle and Bellucci, 2009 and Garzia and Viotti, 2011) another theory argues that, as parties move away from society and secondary organizations and become more personalized, more cognitively skilled citizens are more likely to be involved in ever more "attitudinal" objects like contemporary Italian parties. In conclusion, in addition to a change in the educational composition of society, future studies dealing with CM may therefore also find it productive to take into account the characteristics of the national political context and of the party structure, within a longitudinal cross-country research design. The current study has indeed been focussing only on the demand side of participation, looking at the characteristics of the citizens, but it should not be forgotten that an offer side of participation exists and affects participatory dynamics. A combined focus on citizens and political parties, with the changes that both sides have undergone over time, could shed more lights on democratic participatory trends. 


\section{Acknowledgements}

I would like to thank Paolo Segatti, Sara Hobolt and Davide Vampa, as well as two anonymous reviewers of Electoral Studies for their constructive remarks and suggestions on an earlier draft of this manuscript.

\section{References}

Albright, J.J., 2009. Does political knowledge erode party attachments? A review of the cognitive mobilization thesis. Elect. Stud. 28 (2), 248-260.

Almond, G., Verba, S., 1963. The Civic Culture: Political Attitudes and Democracy in Five Nations. Princeton University Press, Princeton, NJ. Arzheimer, K., 2006. Dead man walking. Party identification in Germany, 1977-2002. Elect. Stud. 25, 791-807.

Bell, A., Jones, K., 2014. Another 'futile quest'? A simulation study of Yang and Land's hierarchical age-period-cohort model. Demogr. Res. 30 (11), 333-360.

Barnes, S.H., Kaase, M., 1979. Mass Participation in Five Western Democracies. Sage, Beverly Hills.

Barton, T., Dooring, H., 1986. Weakening partisanship and the higher educated in Britain. Eur. J. Polit. Res. 14, 521-542.

Bartolini, S., Mair, P., 1990. Identity, Competition and Electoral Availability. The Stabilization of European Electorates 1885-1985. Cambridge University Press, Cambridge.

Bartolini, S., 2000. The Political Mobilization of the European Left, 1860-1980. The Class Cleavage. Cambridge University Press, Cambridge.

Bartle, J., Bellucci, P., 2009. Introduction. In: Bartle, J., Bellucci, P. (Eds.), Political Parties and Partisanship: Social Identities and Individual Attitudes. Routledge, London, pp. 125.

Bellucci, P., Segatti, P., 2010. Votare in Italia: 1968- 2008. Dall'Appartenenza Alla Scelta (Bologna: Il Mulino).

Berglund, F., Holmberg, S., Schmitt, H., Thomassen, J., 2005. Party identification and party choice. In: Thomassen, J. (Ed.), The European Voter. Oxford University Press, Oxford, pp. 105-123. 
Checchi, D., Leonardi, M., Fiorio, C., 2006. Sessanta Anni di Istruzione Scolastica in Italia. Riv. Polit. Econ. 7-8, 285-318.

Corbetta, P., 2002. Le Generazioni Politiche. In: Caciagli, M., Corbetta, P. (Eds.), Le ragioni dell'elettore: perche ha vinto il centro-destra nelle elezioni italiane del 2001 (Bologna: Il Mulino), pp. 79-111.

Corbetta, P., Ceccarini, L., 2010. Le variabili socio-demografiche: generazione, genere, istruzione e famiglia. In: Bellucci, P., Segatti, P. (Eds.), Votare in Italia: 1968-2008. Dall'appartenenza Alla Scelta (Bologna: Il Mulino), pp. 83-148.

Dalton, R.J., 1984. Cognitive mobilization and partisan dealignment in advanced industrial democracies. J. Polit. 46 (1), 264-284.

Dalton, R.J., 2002. Citizen Politics: Public Opinion and Political Parties in Advanced Industrial Democracies, third ed. (Chatham, NJ: Chatham House/Seven Bridges).

Dalton, R.J., 2007. Partisan mobilization, cognitive mobilization and the changing American electorate. Elect. Stud. 26 (2), 274-286.

Dalton, R.J., 2012. Apartisans and the changing German electorate. Elect. Stud. 31, 35-45.

Dalton, R.J., 2013. The Apartisan American: Dealignment and Changing Electoral Politics. CQ Press, Washington, DC.

Dalton, R.J., 2014. Intepreting partisan dealignment in Germany. Ger. Polit. 23, 134-144.

Dalton, R.J., Wattenberg, M.P. (Eds.), 2000. Parties without Partisans. Political Change in Advanced Industrial Democracies. Oxford University Press, New York.

Dassonneville, R., Hooghe, M., Vanhoutte, B., 2012. Age, period and cohort. Effects in the decline of party identification in Germany: an analysis of a two decade panel study in Germany (1992-2009). Ger. Polit. 21 (2), 209-227.

Franklin, M., 2004. Voter Turnout and the Dynamics of Electoral Competition in Established Democracies since 1945. Cambridge University Press, Cambridge.

Fuchs, D., Klingemann, H.-D. (Eds.), 1995. Citizens and the State. Oxford University Press, Oxford.

Garzia, D., Viotti, F., 2011. Leader, identita di partito e voto in Italia, 1990-2008. Riv. Ital. Sci. Polit. 41, 411-432. 
Glenn, N.D., 1976. 'Cohort analysis' futile quest: statistical attempts to separate age, period and cohort effects. Am. Sociol. Rev. 41 (5), 900-904.

Gunther, R., Diamond, L., 2003. Species of political parties a new typology. Party Polit. 9 (2), 167-199.

Huber, J.D., Kernell, G., Leoni, E.L., 2005. Institutional context, cognitive resources and party attachments across democracies. Polit. Anal. 13 (4), 365-386.

Hyman, H.H., Wright, C.R., 1979. Education's Lasting Influence on Values. University of Chicago Press, Chicago.

Ignazi, P., 2012. Forza senza legittimita: il vicolo cieco dei partiti (Laterza: Bari).

Inglehart, R., 1977. The Silent Revolution: Changing Values and Political Styles Among Western Publics. Princeton University Press, Princeton, NJ.

Inglehart, R., 1990a. Culture Shift in Advanced Industrial Society. Princeton University Press, Princeton, NJ.

Inglehart, R., 1990b. Values, Ideology and Cognitive Mobilization in New Social Movements. In: Dalton, R.J., Kuechler, M. (Eds.), Challenging the Political Order: New Social and Political Movements in Western Democracies. Oxford University Press, Oxford, pp. 43-66.

Katz, R.S., Mair, P., 1995. Changing models of party organization and party democracy: the emergence of the cartel party. Party Polit. 1 (1), 5-28.

Mair, P., Van Biezen, I., 2001. Party Membership in Twenty European Democracies, 19802000. Party Politics 7, 5-21.

Mannheim, K., 1964. The problem of generations. In: Mannheim, K. (Ed.), Essay on the Sociology of Knowledge. Routledge, London.

Mannheimer, R., Sani, G., 1987. Il Mercato Elettorale (Bologna: Il Mulino).

Marthaler, S., 2008. The paradox of the politically-sophisticated partisan: the French case. West Eur. Polit. 31 (5), 937-959.

Neundorf, A., Niemi, R.G., 2014. Special symposium: beyond political socialization: new approaches in age, period, cohort analysis. Elect. Stud. 33, 1-101. 
Norris, P., 1999. Critical Citizens: Global Support for Democratic Government: Global Support for Democratic Government. Oxford University Press, Oxford.

Ohr, D., Dülmer, H., Quandt, M., 2009. Kognitive mobilisierung oder nicht-kognitive demobilisierung? In: Gabriel, O., Wessels, B., \& J Falter (Eds.), Wahlen und Wahler: Analysen aus Anlass der Bundestagswahl 2005. VS Verlag für Sozialwissenschaften, Wiesbaden, pp. 536- 558.

Panebianco, A., 1982. Modelli di Partito (Bologna: Il Mulino).

Pasquino, G., 2001. The new Campaign in Southern Europe. In: Diamandouros, P.N., Gunther, R. (Eds.), Parties, Politics and Democracy in the New Southern Europe. Johns Hopkins University Press, Baltimore, MD, pp. 183-223.

Pharr, S.J., Putnam, R.D., 2000. Disaffected Democracies: What's Troubling the Trilateral Countries? Princeton University Press, Princeton, NJ.

Pizzorno, A., 1980. I Soggetti del Pluralismo: Classi, Partiti, Sindacati (Bologna: Il Mulino).

Sani, G.,1980. The Political Culture of Italy: Continuity and Change. In: Almond, G.A., Verba, S. (Eds.), The Civic Culture Revisited. Little, Brown and Co., Boston, pp. 273324.

Van Biezen, I., Mair, P., Poguntke, T., 2012. Going, Going...Gone? Eur. J. Polit. Res. 51, 2456.

Verba, S., Schlozman, K.L., Brady, H.E., 1995. Voice and Equality: Civic Voluntarism in American Politics. Harvard University Press, Cambridge, Mass.

Van Deth, J.W., 2000. Interesting but irrelevant: social capital and the saliency of politics in Western Europe. Eur. J. Polit. Res. 37 (2), 115-147.

Van de Werfhorst, H., De Graaf, N., 2004. The sources of political orientations in postindustrial society: social class and education revisited. Br. J. Sociol. 55, 211-235.

Weakliem, D.L., 2002. The effects of education on political opinions: an international study. Int. J. Public Opin. Res. 14 (2), 141-157.

Yang, Y., Land, K.C., 2006. A mixed models approach to the age-period-cohort analysis of repeated cross-section surveys, with an application to data on trends in verbal test scores. Sociol. Methodol. 36 (1), 75-97. 
Yang, Y., Land, K.C., 2008. Age-period-cohort analysis of repeated cross-section surveys. Fixed or random effects? Sociol. Methods Res. 36 (3), 297-326.

Zelle, C., 1995. Social dealignment versus political frustration: contrasting explanations of the floating vote in Germany. Eur. J. Polit. Res. 27, 319-345. 